\title{
Toward the identification of genetic determinants of breast cancer immune responsiveness
}

\author{
Ines Simeone ${ }^{1}$, Wouter Hendrickx², Lance Miller ${ }^{3}$, Halima Bensmail', Ena Wang ${ }^{2}$, Francesco Marincola², \\ Michele Ceccarelli ${ }^{1}$, Davide Bedognetti $i^{*^{*}}$
}

From Breast Cancer Immunotherapy Symposium (BRECIS), part of the Sidra Symposia Series, held in partnership with the Society for Immunotherapy of Cancer

Doha, Qatar. 13-14 April 2015

Overlapping immune signatures are observed among cancers with a better prognostic connotation and those with an increased likelihood to respond to immunotherapeutic approaches $[1,2]$. Such signatures qualitatively overlap with those detected during other conditions of immune-mediated tissue destruction such as flares of autoimmunity or allograft rejection [3]. These pathways reflect a process characterized by the coordinated activation of interferon stimulated genes (ISGs), the recruitment of cytotoxic cells through the production of specific chemokine ligands (CXCR3 and CCR5 ligands), and the activation of immune effector function (IEF) genes [4]. We refer to these genes as the Immunologic Constant of Rejection (ICR) [2-4]. Here, we tested upfront the prognostic role of the ICR genes in the TCGA (The Cancer Genome Atlas) breast cancer database. We show that ICR genes can segregate breast cancers in different immune phenotypes characterized by distinctive prognostic connotations. Whether the favorable cancer immune phenotype is driven by the intrinsic genetics of the tumor cells is presently unknown. By mining copy number variation, gene-expression, and exome sequencing data we are currently characterizing breast cancer somatic alterations implicated in the development of this favorable cancer immune phenotype. The results of this analysis will be presented and discussed.

\section{Authors' details}

${ }^{1}$ Qatar Computing Research Institute, Doha, Qatar. ${ }^{2}$ Sidra Medical and Research Center, Doha, Qatar. ${ }^{3}$ Wake Forest School of Medicine, Winston Salem, NC, USA.

Published: 14 August 2015

\section{References}

1. Bedognetti D., Spivey T. L., Zhao Y., Uccellini L., Tomei S., Dudley M. E., Ascierto M. L., De Giorgi V., Liu Q., Delogu L. G., Sommariva M., Sertoli M. R., Simon R., Wang E., Rosenberg S. A., Marincola F. M.: CXCR3/CCR5 pathways in metastatic melanoma patients treated with adoptive therapy and interleukin-2. British journal of cancer 2013, 109(9):2412-23.

2. Galon J., Angell H. K., Bedognetti D., Marincola F. M.: The Continuum of Cancer Immunosurveillance: Prognostic, Predictive, and Mechanistic Signatures. Immunity 2013, 39(1):11-26.

3. Spivey T. L., Uccellini L., Ascierto M. L., Zoppoli G., De Giorgi V., Delogu L. G., Engle A. M., Thomas J. M., Wang E., Marincola F. M., Bedognetti D.: Gene expression profiling in acute allograft rejection: challenging the immunologic constant of rejection hypothesis. J Trans/ Med 2011, 9:174.

4. Wang E., Bedognetti D., Marincola F. M.: Prediction of Response to Anticancer Immunotherapy Using Gene Signatures. J Clin Oncol 2013, 31(19):2369-2371.

doi:10.1186/2051-1426-3-S1-P1

Cite this article as: Simeone et al:: Toward the identification of genetic determinants of breast cancer immune responsiveness. Journal for ImmunoTherapy of Cancer 2015 3(Suppl 1):P1.

Sidra Medical and Research Center, Doha, Qatar

Full list of author information is available at the end of the article

Submit your next manuscript to BioMed Central and take full advantage of:

- Convenient online submission

- Thorough peer review

- No space constraints or color figure charges

- Immediate publication on acceptance

- Inclusion in PubMed, CAS, Scopus and Google Scholar

- Research which is freely available for redistribution

Submit your manuscript at www.biomedcentral.com/submit
() Biomed Central 